\title{
Больше, чем пропаганда: активные советские мероприятия в путинской России
}

\section{Стив Абрамс}

Резюме: В этой работе рассматривается роль «активных мероприятий» в советском стиле в качестве элемента современного арсенала российской «политической войны». Эти методы, широко используемые в советской эпохе, охватывают широкий спектр деятельностей для оказания давления, в том числе: скрытое размещение публикаций в СМИ, подлог, использование агентов влияния, общества "дружбы», подставные организации и другие. Сегодня, в путинской России, снова используются эти активные мероприятия, модернизированные для взаимосвязанного цифровыми технологиями «глобального информационного пространства». Работа начинается обзором активных мероприятий, затем рассматривается их роль в советской внешней политике и попытки американской «Рабочей группы по активным мероприятиям» им противодействовать. Далее в работе показано, как набор советских активных мероприятий был обновлен для современной эпохи на примере трех исследований конкретных случаев. Работа заканчивается рассмотрением стратегии, воспроизводящей рекомендации из ключевых публикаций.

Ключевые слова: активные мероприятия, агент влияния, отвлекающие действия, дезинформация, гибридная война, подрывная деятельность, КГБ, Россия, силовики.

\section{Предисловие: пробуждение}

Самый хитрый трюк дьявола заключается в том, чтобы убедить вас, что он не существует. - Шарль Бодлер, $1869^{1}$

Они начали появляться в конце февраля 2014 года. Оснащенные последними моделями военного оружия и экипировкой, без знаков различия и

1 Charles Baudelaire, Paris Spleen: Little Poems in Prose, trans. Keith Waldrop (Middletown, CT: Wesleyan University Press, 2009), 60. 
на необозначенных военных транспортных средствах, они быстро захватывали территорию. ${ }^{2}$ Пока мир смотрел в растерянности, в течение нескольких недель все закончилось; Крым принадлежал Маленьким зеленым человечкам.

Через несколько месяцев, после полудня в один прекрасный июльский день, дождь из композитных и алюминиевых частей самолета неожиданно затемнил голубое небо Восточной Украины, падая на поля подсолнуха рядом с Грабово. 298 пассажиров и экипаж рейса 17 Малазийских авиалиний погибли, когда их Боинг 777 был сбит ракетой 9М38 российского производства, запущенной из противовоздушной системы Бук-М1. ${ }^{3}$ Длиной в 18 футов, ракета имела приблизительно размер телефонного столба и летела со скоростью, превышающей в три раза скорость звука.

За ширмой потока спонсированной государством пропаганды, Кремль поддерживал предположение о своей невиновности, дистанцируя Россию от противоречивых событий и категорически отрицая свою причастность несмотря на увеличивающиеся свидетельства о противоположном.

Для большой части западной аудитории первое знакомство с современной российской пропагандой произошло в неистовом круговороте в связи с этими драматическими событиями. Описываемая как «мрачно, мерзко блестящая» и «гораздо более изощренная, чем советская пропаганда», в течение полутора лет после незаконного крымского референдума о независимости, журналистские наблюдения и теоретические анализы пропаганды в телевизионной сети РТ (бывшая «Россия сегодня») и других способствовали повышению осведомленности о координированной манипуляции Кремля российскими средствами массовой информации. ${ }^{4}$

К несчастью, РТ и другие контролируемые государством средства массовой информации являются всего лишь одной гранью гораздо более широкой кампании воздействия - одним из инструментов в наборе недостаточно изученных действий, которые составляют тревожный пробел в более широком «мягком сдерживании» России Путина Западом.

2 Arto Pulkki, "Crimea Invaded by High Readiness Forces of the Russian Federation," Suomen Sotilas, 3 March 2014.

3 Nick Miller, "MH17 Plane Was Shot Down by a Buk Missile, Russian Weapons Manufacturer Says," The Age, 3 June 2015, доступно на www.theage.com.au/world/ mh17-plane-was-shot-down-by-a-buk-missile-russian-weapons-manufacturer-says20150602-ghfdco.html (по состоянию на 9 августа 2015); Dutch Safety Board, Crash of Malaysia Airlines Flight MH17 (The Hague: Dutch Safety Board, 2015), 9, доступно на http://onderzoeksraad.nl/en/onderzoek/2049/investigation-crash-mh17-17-july2014 (по состоянию на 11 февраля 2016).

4 David Remnick, цитированный в Peter Pomerantsev and Michael Weiss, The Menace of Unreality: How the Kremlin Weaponizes Information, Culture and Money (New York, NY: The Institute of Modern Russia, 2014), 14. 


\section{Введение в «Активные мероприятия»}

Вкратие, советский подход к международным отношениям можно описать как форму "политической войны», с манипулятивными и вводящими в заблуждение методами активных мероприятий, играющих существенную и важную роль.

- Доклад ЮСИА, Советские активные мероприятия в период после Холодной войны, 1988-1991 ${ }^{5}$

В настоящее время Российская Федерация ведет «наиболее удивительный информационный блицкриг ... в истории информационной войны», следуя реваншистской внешней политике, которую высшие дипломатические и военные руководители считают огромной угрозой для безопасности, как Европы, так и Америки. ${ }^{7}$ Хотя многие на Западе сейчас знакомы с пресловутой российской сетью РТ, ее спонсированные государством средства массовой информации явля-

Наиболее могущественный враг может
быть полностью побежен только при-
кладыванием величайших усилий, и наибо-
лее тщательным, внимательным, уме-
лым и обязательным использованием лю-
бой, даже самой мелкой, размолвки
между врагами, любого конфликта инте-
ресов между буржуазией разных стран и
между разными группами или видами
буржуазии в разных странах, и использо-
ванием любой, даже самой незначитель-
ной возможности, получить массового
союзника, даже если это союзник времен-
ный, нерешительный, неустойчивый, не-
надежный и условный.
- Владимир Ленин

Наиболее могущественный враг может быть полностью побежден только прикладыванием величайших усилий, и наиболее тщательным, внимательным, умелым и обязательным использованием любой, даже самой мелкой, размолвки между врагами, любого конфллита интересов между буржуазией разных стран и между разными группами или видами буржуазии в разных странах, и использованием любой, даже самой незначительной возможности, получить массового союзника, даже если это союзник временный, нерешительный, неустойчивый, не- Владимир Ленин ${ }^{6}$

5 United States Information Agency, Soviet Active Measures in the "Post-Cold War" Era (Washington, D.C.: 1992), доступно на http://intellit.muskingum.edu/russia_folder/ pcw_era/index.htm\#Contents (по состоянию на 19 августа 2015). Этот документ архивирован в цифровом формате в разделах с гиперссылками. Эта цитата находится в разделе под наименованием «Роль активных мероприятий в советской внешней политике».

6 Там же, цитата в разделе под наименованием «Советское понимание компромисса и примирения».

7 Michael Birnbaum, "Fearing Russian Expansion, Baltic Nations Step Up Military Exercises," The Washington Post, 16 May 2015, www.washingtonpost.com/world/ europe/fearing-russian-expansion-baltic-nations-step-up-military-exercises/2015/ 05/15/b5ee51ee-f8c8-11e4-a47c-e56f4db884ed_story.html (по состоянию на 17 мая 2015); Ian Johnston, “'Russia's Growing Threat: After Ukraine, Fears Grow That Baltic States Could Be Vladimir Putin's Next Targets," The Independent, 8 February 2015, http://www.independent.co.uk/news/world/europe/russias-growing-threatafter-ukraine-fears-grow-that-baltic-states-could-be-vladimir-putins-next-targets10032378.html (по состоянию на 19 августа 2015); Jamie Crawford, "Joint Chiefs Nominee: Russia Greatest Threat to U.S.," CNN Politics, 10 July 2015, www.cnn.com/ 2015/07/09/politics/joseph-dunford-russia-greatest-threat/index.html (по состоянию на 17 августа 2015). 
ются только верхушкой айсберга - элемент «белой пропаганды» в гораздо более широкой системе действий по оказанию давления, предназначенной для формирования глобального информационного пространства.

Уходя корнями в ленинское мышление, поколение советов усовершенствовали набор методов, известный как «активные мероприятия», простирающийся от простой пропаганды и подлога до политических убийств, терроризма и всего, что находится между ними. На Западе такая политика другими средствами просто называлась «грязные махинации». ${ }^{8}$

Описываемые генерал-майором Олегом Калугиным, наиболее высокопоставленным перебежчиком из КГБ, как «душа и сердце советской разведки», эти «активные мероприятия были интегрированы в советскую политику и включали практически каждый элемент советской партийной и государственной структуры, а не только КГБ». ${ }^{9}$ Как основной элемент советской внешней политики, эти методы были невероятно хорошо обеспечены ресурсами. По мнению экспертов, «аппарат советских активных мероприятий превышал в 20 или 30 раз правительственный аппарат США, созданный для анализа и противодействия его деятельности». ${ }^{10} \mathrm{Hа} \mathrm{пике}$ своего развития, по некоторым оценкам, на кампанию советских активных мероприятий работало до 15000 людей - больше, чем число дипломатов, служащих в Государственном департаменте США после 9/11. ${ }^{11}$

Даже на пике Холодной войны, несмотря на ее массовый характер, не было полного понимания использования этих программ Советским Союзом, и сегодня, широко упоминаемые под двусмысленным ярлыком «гибридная война» и «злокачественное влияние», эти методы имеют еще

8 "Soviet Active Measures," YouTube video, 23:31, posted by PublicResourceOrg, 9 December 2010, https://www.youtube.com/watch?v=Z-X_bXL2Tgo (по состоянию на 19 августа 2015).

9 "Inside the KGB - An interview with retired KGB Maj. Gen. Oleg Kalugin," Cold War Experience, CNN, January 1998, http://web.archive.org/web/20070627183623/ http://www3.cnn.com/SPECIALS/cold.war/episodes/21/interviews/kalugin (по состоянию на 8 июля 2015). Хотя некоторые считают Калугина противоречивой фигурой, везде, где есть ссылки на него в этом документе, его утверждения подкрепляются другими сведениями с первых рук перебежчиков из КГБ; Thomas Boghardt, "Operation INFEKTION: Soviet Bloc Intelligence and Its AIDS Disinformation Campaign," Studies in Intelligence 53:4 (December 2009), 1-2.

10 Soviet Active Measures in the "Post-Cold War" Era. Цитата из раздела, озаглавленным "White or Overt Active Measures."

11 Pomerantsev and Weiss, The Menace of Unreality, 8; Matthew Asada, Susan Johnson and Cameron Munter, "Diplomacy Post-9/11: Life in the US Foreign Service," interview by Kojo Nnamdi, The Kojo Nnamdi Show, 22 September 2011, http://thekojonnamdishow.org/shows/2011-09-22/diplomacy-post-911-life-us-

foreign-service (по состоянию на 19 августа 2015). Число 15000 упоминается Померанцевым и Вейсом, а число дипломатов в периоде после 9/11 взято из интервью Койо Ннамди. 
меньшее понимание, и их использование в целом забыто - останки Холодной войны. 12

К несчастью, становится ясно, что активные мероприятия советской эпохи живы и процветают в России Путина. Облегченные технологиями и адаптированные для глобализированного мира, их современные воплощения гораздо более зловещи, с большим обхватом и большей скоростью, - и через Интернет они могут оказывать влияние на общественное мнение в таких масштабах, которые прежде были невозможны.

Через Инициативу по обеспечению европейской безопасности и операцию «Атлантическая решимость» США и союзники

Я скажу так, сердием и душой советской разведки была подрывная деятельность. Не сбор разведывательной информации, а подрывная деятельность: активные мероприятия для ослабления Запада, в том числе вбивать клинья между союзниками всех сортов западного сообщества, сеять разногласия между союзниками, ослаблять Соединенные Штаты в глазах народов Европы, Азии, Африки, Латинской Америки, и таким образом, готовить почву на случай, если действительно будет война. Сделать Америку более уязвимой к гневу и недоверию других народов.

Олег Калугин, генерал-майор КгБ

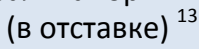

НАТО прилагают усилия для сдерживания российской военной агрессии на флангах Альянса. ${ }^{14}$ США и ЕС наложили на Россию секторные и направленные против отдельных лиц санкции. ${ }^{15}$ Осознание Западом российской пропаганды постепенно расширяется, и по обе стороны Атлантического океана медленно предпринимаются шаги, направленные на уменьшение эффективности и ограничение охвата этой кампании. ${ }^{16}$

Несмотря на усилия, направленные на смягчение российской военной угрозы с одной стороны, и белой пропаганды с другой, по крайней мере для широкой публики, «серая зона» посередине в целом остается без внимания. Это территория ключевого значения - место сражений в кампании активных мероприятий.

12 Dennis Kux, "Soviet Active Measures and Disinformation: Overview and Assessment," Parameters, Journal of the US Army War College 15:4 (Winter 1985), 19.

13 "Inside the KGB."

14 US European Command Communication and Engagement Directorate, "Operation Atlantic Resolve Fact Sheet," 19 February 2015.

15 "Ukraine Crisis: Russia and Sanctions," BBC News, 19 December 2014, www.bbc.com/ news/world-europe-26672800 (по состоянию на 19 августа 2015).

16 Bill Gertz, "House Adds Funds to Counter Russian Info War," Washington Times, 29 April 2015, http://www.washingtontimes.com/news/2015/apr/29/inside-the-ringhouse-funding-bill-targets-russian/ (по состоянию на 19 августа 2015); "Lithuania to Ban Russian TV Channel for 'Warmongering,'” Deutsche Welle, 8 April 2015, http://www.dw.com/en/lithuania-to-ban-russian-tv-channel-for-warmongering/a18370852 (по состоянию на 19 августа 2015). 
Хотя «средства» были обновлены для современной среды, все равно можно провести удивительно близкие параллели между «целями» и «путями» схемы советских активных мероприятий и «враждебным влиянием» России Путина.

Изучая исключительную и забытую работу американских экспертов времен Холодной войны, и осовременивая и адаптируя их уроки тридцатилетней давности, сегодняшние профессионалы в сфере безопасности и журналисты смогут легче идентифицировать и выявлять «грязные трюки» Путина.

\section{Исторические условия: президент Рейган и Рабочая группа по активным мероприятиям}

20 января 1981 года Рональд Рейган был приведен к присяге как 40-й Президент Соединенных Штатов, начиная первый из двух президентских сроков и раскрывая заключительные главы Холодной войны. План Рейгана для завершения конфликта будет детализирован в Директиве о решениях по национальной безопасности (ДРНБ) 75 от 1983 года, но свое видение по этому вопросу он определил на несколько лет раньше. ${ }^{17}$ В одном разговоре в 1977 году с Ричардом В. Алленом, его главным советником по внешней политике, Рейган заявил открыто: «Моя идея об американской политике в отношении Советского Союза проста ... Мы выигрываем, а они проигрывают». ${ }^{18}$

Являясь глубоким сдвигом от сдерживания и разрядки, доктрина Рейгана, став популярной стратегией, обрисованной в ДРНБ 75, предполагала гораздо более агрессивное отношение к Советскому Союзу. Призванная «ускорить кончину Советского Союза» и «снизить» влияние Советов по всему миру, ДРНБ 75 являлась четким стратегическим руководством и привела к широкому применению новых инициатив с использованием всех инструментов национального могущества. ${ }^{19}$

На фоне всех этих трансформаций и драмы высоких ставок рейгановских лет легко не заметить небольшую «межведомственную непостоянную комиссию», известную как Рабочая группа по активным мероприятиям (РГАМ). ${ }^{20}$ Созданная летом 1981 года и представившая свой последний доклад в 1992 году, эта группа работала в течение одиннадцати лет на пике

17 Norman A. Bailey, The Strategic Plan That Won the Cold War: National Security Decision Directive 75 (MacLean, VA: The Potomac Foundation, 1998).

18 Richard V. Allen, "The Man Who Won the Cold War," Hoover Digest, 30 January 2000, http://www.hoover.org/research/man-who-won-cold-war (по состоянию на 6 августа 2015).

19 Bailey, The Strategic Plan.

20 Fletcher Schoen and Christopher J. Lamb, Deception, Disinformation, and Strategic Communications: How One Interagency Group Made a Major Difference (Washington, DC: National Defense University Press, 2012), 3. 
Холодной войны, конец которой обозначил крах Советского Союза. ${ }^{21}$ Сначала ее возглавлял Помощник государственного секретаря Деннис Кукс, и она подчинялась Бюро госдепартамента по разведке и исследованиям. В состав группы входили представители множества заинтересованных ведомств, в том числе из Государственного департамента (ГД), Министерства обороны (МО), Центрального Разведывательного Управления (ЦРУ), Управления военной разведки (УВР), Федерального Бюро Расследований (ФБР), Министерства правосудия (МП), Управления по контролю над вооружениями и разоружением (УКВР - позже включенное в состав Госдепартамента) и (ныне уже не существующего) Информационного агентства США (ЮСИА). ${ }^{22}$

Задача РГАМ состояла в том, чтобы идентифицировать и раскрывать советскую дезинформацию. ${ }^{23}$ В своем комплексном исследовании работы этой группы Шоен и Лэмб писали:

Эта группа успешно определяла и реализовала политику США в ответ на советскую дезинформацию. Она выявляла некоторые советские тайные операции и повышала политическую цену других, доводя до сведения иностранной и внутренней аудитории как ее вводят в заблуждение. Рабочая группа поощряла союзников и заставляла Советский Союз платить за дезинформацию, что имело отголосок до самого верха советского политического аппарата. Она стала экспертным органом правительства по дезинформации и пользовалась большим уважением как в Конгрессе, так и у исполнительной власти. ${ }^{24}$

\section{Что означает это наименование? Определение спектра совет- ских активных мероприятий}

Влияние этой деятельности можно представить следующим образом... представьте себе капли воды, падающие на камень: пять минут, десять минут, пятнадцать минут, один час, один день - ничего не происходит, но пять лет, десять лет, пятнадиать лет - и капля пробивает в камне отверcrmue.

- Деннис Кукс, бывший руководитель Рабочей группы по активным мероприятиям, $1984^{25}$

21 Там же. В 1992 году Информационное агентство США опубликовало, похоже, последний имеющийся в наличии государственный доклад по активным мероприятиям под наименованием «Советские активные мероприятия в эпоху после Холодной войны 1988-1991». Хотя доклад был официально опубликован ЮСИА и в нем нет ссылок на конкретных авторов, почти наверняка этот документ был разработан бывшими экспертами РГАМ, которая была реструктурирована и распущена после Холодной войны.

22 Там же, 35.

23 Там же, 4-5.

24 Там же, 3.

25 "Soviet Active Measures," YouTube video. 
«Термин активные мероприятия ... был объемлющим выражением, которое КГБ использовало для обозначения множества деятельностей по оказанию влияния». ${ }^{26}$ На деле, однако, дать более точное определение затруднительно, так как по мнению бывшего заместителя Государственного секретаря Лоуренса Иглбургера, «нет фразы на английском языке, которая точно передавала бы значение активных мероприятий». ${ }^{27}$

Для межведомственных представителей в РГАМ - американских экспертов по вопросу в период Холодной войны - достижение консенсуса по дефиниции оказалось исключительно сложным. ${ }^{28}$ По существу, этот термин воплощал набор деятельностей, ограниченных только воображением и творческими способностями полмиллиона офицеров КГБ, и мог включать все от простой пропаганды до похищений, убийств, наркоторговли и тайной поддержки терроризма. ${ }^{29}$ За время ее существования члены РГАМ постоянно спорили относительно туманной дефиниции этого выражения: «Госдеп и ЦРУ, по разным причинам, хотели иметь более узкое определение этого понятия», тогда как "другие дефинировали активные мероприятия в более широком смысле, включая явную пропаганду, скрытные действия, стратегическую дезинформацию и другие виды политической войны». ${ }^{30}$ Шоен и Лэмб разъясняли:

Деятельность КГБ по оказанию влияния не включает создание и финанси-
рование подставных групп, тайную трансляцию, манипулирование СМИ,
дезинформацию и подлоги и покупку агентов влияния. Однако, такое по-
нимание активных мероприятий слишком узко. Советские активные меро-
приятия выходили далеко за рамки явных и тайных операций по манипули-
рованию восприятием и включали подстрекательство, убийства и даже тер-
роризм. Советские руководители не делали больших различий между от-
крытой пропагандой и тайными действиями или между дипломатией и по-
литическим насилием.
На практике, все находилось под жестким контролем Политбюро и Сек-
ретариата Коммунистической партии Советского Союза, которые одобряли
главные направления операций с использованием активных мероприятий.

В итоге, затруднения с ответом на такой широкий диапазон деятельностей привели к созданию секретной группы, «которая действовала не под началом администрации Совета Национальной Безопасности (СНБ), ... ис-

26 Schoen and Lamb, Deception, Disinformation, and Strategic Communications, 8. Цитировано в Kux, "Soviet Active Measures and Disinformation," 19-20.

28 Schoen and Lamb, Deception, Disinformation, and Strategic Communications, 66-67.

29 "The Making of a Neo-KGB State," The Economist, 23 August 2007, http://www.economist.com/node/9682621 (по состоянию на 11 августа 2015); Brian Crozier, "The Other Side of Perestroika: The Hidden Dimension of the Gorbachev Era," Demokratizatsiya 4:1 (1996), 48-49. Число 500000 упомянуто в The Economist, а Крозье описывает участие КГБ в незаконном обороте наркотиков.

30 Schoen and Lamb, Deception, Disinformation, and Strategic Communications, 66-67.

31 Там же, 8. 
пользуя большой набор методов и которая занималась более широким спектром советских активных мероприятий, чем группа в составе Госдепа». ${ }^{32}$

Тогда как секретная группа при СНБ предположительно занималась более энергичными и скрытными активными мероприятиями, несекретная рабочая группа сосредоточилась в основном на разоблачении советской дезинформации. Ограничивая «свою миссию до противодействия советским агентам влияния, которые могут быть выявлены убедительным образом с использованием несекретной или рассекреченной информацией» и «направляя свою миссию в практическом плане, группа могла отчитываться об обнаружении дезинформационных проблем, находя способы их решения и добиваясь реальных результатов». ${ }^{33}$ Далее, “скромное определение целей группы и целостный подход к ее миссии позволил ей сосредоточиться на случаях, где успех был более вероятен и обходится меньшим количеством ресурсов, что делало сотрудничество с создавшими ее организациями более легким». ${ }^{34}$

Таким образом, концепция активных мероприятий, предложенная РГАМ Государственного департамента, обеспечивает наиболее подходящую базу для изучения этого вопроса по открытым источникам, и отправную точку для анализа и разоблачения российских активных мероприятий в нынешней оперативной среде.

В своей статье в номере от 1985 года журнала Военного колледжа Сухопутных войск США Параметры, Деннис Кукс рассматривает эту концепцию, предлагая, возможно, наиболее подходящую рамку для понимания советских активных мероприятий - рамку, которую легко можно применить для современного анализа:

Давайте рассмотрим весь спектр советской внешней политики через призму "белых», «серых» и «черных» операций. Нормальные дипломатические, торговые, информационные мероприятия и оказание помощи можно считать «белой» или открытой деятельностью. «Серая» деятельность - это те мероприятия, которые включают участие коммунистических фронтов, иностранных коммунистических партий, «нелегальных» радиостанций или хорошо известные СМИ для распространения дезинформации. Хотя официально не декларируется, что эти мероприятия спонсируются Советами, широко известно, что полуявная “серая» деятельность находится под советским управлением и контролем. «Черная» деятельность, наоборот, включает по настоящему тайные операции: использование агентов влияния, распространение неверных слухов, одурачивание политиков и журналистов и распространение подложных и фальшивых документов. Ак-

\footnotetext{
32 Там же, 8.

33 Там же, 4-5.

34 Там же, 5.
} 
тивные мероприятия попадают в категорию «серой» или «черной» деятельности, хотя граница ... часто размыта. ${ }^{35}$

В томе за 2009 год профессионального журнала ЦРУ Исследования в области разведки показано, что в советской эпохе применялись две основные категории активных мероприятий и описана их реализация:

1) Центр дает стратегическое добро кампании по дезинформации.

2) Сотрудниками на месте, которым поручено штудировать местную прессу, книги и журналы на предмет нахождения материалов, которые можно использовать в целях дезинформации, предлагаются идеи.

3) Центр оценивает эти идеи.

4) Все еще в Центре проводится подготовка, в которой участвуют специалисты, пишущие на родном языке, дается одобрение менеджеров и произ-

Типология тем, посланий и методов актывных мероприятий

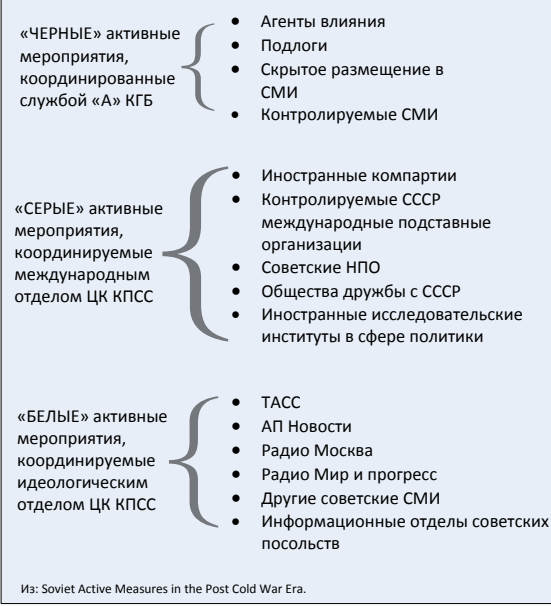
водится перевод.

5) Следует определение целевой аудитории. Центр пытается запустить историю вне прессы, контролируемой советским блоком, с целью прикрыть участие Москвы. Это делалось часто с использованием анонимных писем и газетных статей в Третьем мире.

6) После публикации в заграничных СМИ советские медиа могли подхватить и дальше распространять тему, ссылаясь на несоветский источник.

В первую категорию входят операции, задуманные и начатые в рядах КГБ, и в них используются такие традиционные дезинформационные технологии как подлог или агенты влияния. КГБ вело сотни таких операций каждый год, несмотря на то, что их влияние было весьма ограниченным.

Второй вид операций был результатом стратегических решений на самом верху пирамиды советских активных мероприятий, которые одобрялись напрямую Политбюро. Кампании обычно планировались на несколько лет и охватывали участие множества элементов советского государства, в том числе Отдел по международной информации (ОМИ), который руководил органами официальной печати: ТАСС, Новости и радио

35 Kux, "Soviet Active Measures and Disinformation," 19. 
Москва; и Международный отдел (МО), отвечающий за связи с иностранными коммунистическими партиями, с международными коммунистическими подставными организациями и нелегальными радиостанциями.

КГБ, МО, ОМИ тесно сотрудничали при выполнении конкретных кампаний с использованием средств, находящихся в их распоряжении - службы "А» КГБ, ответственной за фальсификации и распространение слухов («черная пропаганда»), органы печати для официальных позиций ОМИ («белая пропаганда»), МО для нелегальных радиопередач и использования международных подставных организаций («серая пропаганда»). ${ }^{36}$

Появляется все больше доказательств, что подобная система централизованного контроля российской дезинформационной работы и сегодня все еще используется Кремлем. Журналист Петр Померанцев и другие бывшие сотрудники СМИ рассказывают о собственном опыте в этой системе. Российские дезинформационные кампании, как и советские, похоже, контролируются и координируются на самом высоком уровне в руководстве Кремля. $^{37}$

\section{Прошлое является прологом}

ЮСИА опубликовала последний доклад об активных мероприятиях в 1992 году, но не потому, что кампании Кремля по оказанию влияния перестали существовать. ${ }^{39}$ Доклад, озаглавленный «Советские активные мероприятия в эпохе после Холодной войны 1988-1991» выявляет несколько интересных явлений, которые имели место в сумрачные годы CCCP.
Как и приверженные к жесткой линии бывшие коммунистические силы, так и российское руководство принимают участие в активных мероприятиях и операциях по дезинформации, преследуют свои политические цели. Следует ожидать, что обе эти группы активно будут продолжать осуществление таких операций.

Пока в России не установится истинно демократический режим, который полностью разделяет западные идеалы правды, честности, открытости и взаимной выгоды, те, кто у власти, или которые борются за власть, скорее всего, будут считать выгодным продолжать активные мероприятия и операции по дезинформации.

- доклад ЮСИА, Советские активные мероприятия в эпоху после Холодной войны, 1988-1991

36 Boghardt, "Operation INFEKTION: Soviet Bloc," 3.

37 Carl Schreck, "Russian TV Deserters Divulge Details On Kremlin's Ukraine 'Propaganda,'” Radio Free Europe/Radio Liberty, 7 August 2015, www.rferl.org/ content/russian-television-whistleblowers-kremlin-propaganda/27178109.html (по состоянию на 12 августа 2015); Pomerantsev and Weiss, The Menace of Unreality.

38 Soviet Active Measures in the "Post-Cold War" Era. Цитата из раздела, озаглавленным "Looking to the Future."

39 смотри замечание 21. 
После конца Холодной войны, хотя использование «грубой антиамериканской дезинформации» ослабло, аппарат КГБ для активных мероприятий перенаправил свои усилия, усилив атаки на ряд новых целей. ${ }^{40} \mathrm{C}$ приближением краха Советского Союза новые кампании влияния сосредоточились на обеспечение сохранения советского статус-кво и существующих структур власти.

В начале 1990-х КГБ не только усилило свою «дискредитирующую дезинформацию против ... внутренних врагов» советской коммунистической партии, но также «инициировало большую кампанию активных мероприятий, направленную на создание мягкого, и фальшивого, образа КГБ». ${ }^{41}$ Что касается Запада, “Советские власти целенаправленно пытались оказывать влияние на западную политику», распространяя «паникерские темы для активных мероприятий в попытке использовать в свою пользу страхи Запада от распада СССР». ${ }^{42}$

К сожалению, доклад 1992 года РГАМ был последним в своем роде и его авторы хорошо осознавали это. С учетом этого, они представили ряд прогнозов и предупреждений об использовании активных мероприятий новой Россией и ее бывшими республиками, констатируя, что «большие части советского аппарата активных мероприятий продолжают существовать и работать, по большей части под российским, чем под советским покровительством». ${ }^{43}$

После Холодной войны и победы над «Красной угрозой» внимание Запада, в принципе, могло перенестись от бывшего Советского Союза на чтонибудь другое. Запад начал уменьшать военные расходы, сокращать программы и освобождаться от экспертов и устаревшей инфраструктуры, направляя сэкономленные средства на внутренние приоритеты - так называемые «мирные дивиденды».

Хотя угроза ядерной войны была отклонена, в 90-х появились новые конфликты и угрозы, которые привлекли внимание Америки: нападение Саддама Хусейна на Кувейт в 1990 году и последовавшие операции «Пустынная буря» и «Пустынный щит», десятилетие конфликтов и геноцид в бывшей Югославии, появление Аль-Каиды и «новая» угроза терроризма, примерами которой являлись взрывы в Центре мировой торговли в 1993, в Оклахома Сити в 1995, в Сентениел парк в 1996, в небоскребах «Хобар» в 1996 и в посольствах США в Танзании и Найроби в 1998.

Тем временем, отправив КГБ и его инструменты «политической войны» в историческую литературу, из пепла Советского Союза начала появляться новая, капиталистическая Россия, с могучими олигархами, выкачиваю-

40 Soviet Active Measures in the "Post-Cold War" Era. Цитата из раздела "Crude, AntiAmerican Disinformation."

41 Там же. Цитата из раздела "Executive Summary."

42 Там же. Цитата из раздела "Executive Summary."

43 Там же. Цитата из раздела под наименованием "Еxecutive Summary." 
щими государственные ресурсы и создававшими систему «клептократии», порождая «мафиозное государство», которое привело Россию в эпоху путинизма. $^{44}$

\section{Вертикаль власти: Владимир Путин и силовики}

Нет такого понятия, как бывший сотрудник КГБ. - Владимир Путин, $2006^{45}$

Подрастая в послевоенном Ленинграде, «под влиянием фильмов и книг», молодой Путин был очарован миром шпионажа и решил сделать карьеру в КГБ. ${ }^{46}$ После окончания университета в 1975 году он официально вошел в ряды КГБ, начав продлившуюся 16 лет карьеру и достигнув звания подполковника до того, как ушел со службы в 1991. ${ }^{47}$ После КГБ он вошел в политику, проработав заместителем мэра Санкт-Петербурга до 1996 года. $^{48}$ В июле 1998 года он вернулся в службу безопасности, где Президентом Борисом Ельциным был назначен Директором Федеральной Службы Безопасности (ФСБ) и стал отвечать за прямой постсоветский наследник КГБ. ${ }^{49}$

Официальная кремлевская биография Путина дает очень неинтересный обзор его разведывательной карьеры, хронология, которая преуменьшает его успехи и противоречит официальным отчетам, в некоторых из которых сказано, «что Путин активно участвовал в некоторых самых приоритетных операциях КГБ в 1980-х и 1990-х». 50

Для «человека без лица» (цитируя журналистку Машу Гессен) едва ли когда-нибудь появится точный и открытый отчет о работе в КГБ, правда, о прошлом Путина скорее всего останется в сфере предположений. ${ }^{51}$ Од-

44 David Remnick, "Watching the Eclipse," The New Yorker, 11 August 2014, http://www.newyorker.com/magazine/2014/08/11/watching-eclipse (по состоянию на 19 августа 2015); "Wikileaks: Russia Branded 'Mafia State' in Cables," BBC News, 2 December 2010, http://www.bbc.com/news/world-us-canada-11893886 (по состоянию на 19 августа 2015).

45 Цитировано в Anna Nemtsova, "A Chill in the Moscow Air," Newsweek, 5 February 2006, http://www.newsweek.com/chill-moscow-air-113415 (по состоянию на 19 августа 2015).

46 Цитировано в “Vladimir Putin: Biography," Vladimir Putin Personal Website, http://eng.putin.kremlin.ru/bio (19 августа 2015); Masha Gessen, "Portrait of the Young Vladimir Putin," Newsweek, 2 February 2012, www.newsweek.com/portraityoung-vladimir-putin-65739 (по состоянию на 11 августа 2015).

47 "Russia 2000 Part 2: The Face of Russia to Come," Stratfor Global Intelligence, 11 October 1999, https://www.stratfor.com/sample/analysis/russia-2000-part-2-facerussia-come (по состоянию на 15 августа 2015).

48 "Vladimir Putin: Biography"; "Russia 2000 Part 2"; Gessen, "Portrait of the Young Vladimir Putin."

49 Там же.

50 "Russia 2000 Part 2."

51 Сравни Masha Gessen, The Man Without a Face: The Unlikely Rise of Vladimir Putin (New York: Riverhead, 2012). 
нако, кажется ясным, что он работал в Первом главном управлении КГБ (отвечающее за внешнюю разведку) в самый разгар Холодной войны, в период, который совпадал с существованием РГАМ Государственного департамента США.

В качестве офицера советской эпохи Первого главного управления, от Путина «ожидалось уделять 25 \% своего времени для придумывания и реализации [активных мероприятий]». ${ }^{52}$ Впервые он, наверное, научился использовать эти умения в 1975 году в ходе начальной подготовки и индоктринации в Школе КГБ № 1, и наверное, усовершенствовал их в 1984 году во время своей учебы в элитном краснознаменном институте им. Андропова. ${ }^{53}$ После 16 лет службы в КГБ, и затем в качестве главы ФСБ, нет сомнений, что Путин, как и все офицеры КГБ его времени, хорошо подготовлен для использования активных мероприятий в качестве инструмента внешней политики.

С момента своего назначения действующим президентом в 1999 году, Путин систематически консолидировал власть, создавая сеть из доверенных друзей и ветеранов служб безопасности, занимающих влиятельные должности в государственном управлении и в российском обществе в целом. ${ }^{54}$ Эта система стала известна как "Вертикаль власти», а ее влиятельные фигуры как «силовики» или «властовики». ${ }^{55}$ Эти так называемые «секюрократы» «проникают во все сферы российской жизни. Их можно найти не только в органах охраны правопорядка, но в министерствах экономики, транспорта, природных ресурсов, сообщений и культуры. Несколько ветеранов КГБ занимают высшие должности в Газпроме, самой большой российской компании, и в ее карманном банке Газпромбанк». ${ }^{56}$ Давая поучительную оценку этого явления, исследователь Ольга Крыштановская констатировала, что 80 \% российской элиты связана со службами безопасности. ${ }^{57}$ Похоже, что на самом деле Путин создал «нео-КГБ государство». ${ }^{58}$

Кроме того, Путин возглавляет Российскую Федерацию более 15 лет, в 2008 поменявшись ненадолго с Дмитрием Медведевым в качестве премьер-министра, прежде чем вернуться на должность президента путем сомнительного толкования российской конституции. После того как в 2008

52 Boghardt, "Operation INFEKTION: Soviet Bloc," 1.

53 "Vladimir Putin: Biography"; "Russia 2000 Part 2"; Gessen, "Portrait of the Young Vladimir Putin."

54 Andrei Illarionov, "The Siloviki in Charge," Journal of Democracy 20:2 (April 2009): 70-71.

55 "The Making of a Neo-KGB State."

56 Выражение секюрократы появляется в Illarionov, "The Siloviki in Charge," 69; "The Making of a Neo-KGB State" описывает охват их проникновения.

57 "Russia: Expert Eyes Security Ties Among Siloviki," Radio Free Europe / Radio Liberty, www.rferl.org/content/article/1073593.html (по состоянию на 26 июля 2015).

58 "The Making of a Neo-KGB State." 
году Медведев удлинил срок полномочий президента до шести лет, даже без дальнейших манипуляций конституцией, Путин может остаться президентом Российской Федерации до 2024 года - пережив Барака Обаму, и возможно, следующих двух президентов США. ${ }^{59}$

Вероятность продолжающегося управления Путина, в сочетании с живучестью его огромной сети силовиков (которая скорее всего переживет эпоху Путина), как бы предопределяет, что активные мероприятия продолжать играть ключевую роль в российской внешней политике в обозримом будущем. Сейчас, когда надежды, связанные с годами «перезагрузки» стали далеким прошлым, Запад должен понять важную роль активных мероприятий в российской внешней политике и предпринять срочные шаги для повышения информированности и снижения эффективности этих «грязных трюков» в современной эпохе.

\section{Все новое - это хорошо забытое старое}

После роспуска РГАМ стало гораздо труднее представлять конкретные доказанные свидетельства о российских активных мероприятиях, и степень их использования в 90-х остается в целом неизвестной. Отчеты об их использовании, однако, стали появляться после того, как к власти в 1999 году пришел Путин.

В открытых источниках сведения о том, что Россия снова использует активные мероприятия в качестве элемента внешней политики, появились в 2008 году в ежегодном докладе чешской информационной службы безопасности - эквивалентной американскому ФБР. Авторы однозначно заявляют, что «операции разведывательных служб Российской Федерации ... к настоящему времени наиболее активны на нашей территории. Таким образом подтверждается предположение, что Россия восприняла советскую практику использовать активные мероприятия для реализации своих внешнеполитических интересов». ${ }^{60}$ Дальше в докладе подчеркивается, что «формы и методы, которые используют российские разведывательные службы в своей работе, в значительной степени инспирированы формами и методами, успешно применяемыми советским шпионажем в 1980-х годах». ${ }^{61}$

Через семь лет после чешского доклада, с учетом уроков Крыма, Восточной Украины и полета МH17, кажется, что предсказания, сделанные в финальном докладе РГАМ от 1992 года, так же подтверждаются. Сегодня можно с уверенностью утверждать, что использование Кремлем активных

$59 \mathrm{Jim}$ Nichol, Russian Political, Economic, and Security Issues and US Interests (Congressional Research Service, 2014), 6-7.

60 Security Information Service of the Czech Republic, Annual Report of the Security Information Service (BIS) (2008), 5.

61 Там же, 5. 
мероприятий во внешней политике не закончилось с крахом Советского Союза.

Использование активных мероприятий в современной российской политической войне является просто продолжением длившейся десятки лет советской политики, которая сама по себе есть отражение методов российской империи. ${ }^{62}$ В 21 веке Россия просто повторно использует и обновляет эти очень давние методы подрывной деятельности для применения в связанном цифровыми технологиями и глобализованном мире - единой мировой информационной сферы, описанной советскими мыслителями более 25 лет тому назад. ${ }^{63}$

\section{Знакомьтесь: новые старые трюки}

Хотя цели и методы путинских активных мероприятий в целом аналогичны целям и методам активных мероприятий советской эпохи, многие из этих средств были модернизованы для современной среды. В некоторых случаях, старые методы были полностью вытеснены: исчезли пишущие машинки и кампании по распространению писем, их заменили счетчики просмотров, ретвиты и «фабрики троллей». В других случаях старые технологии все еще эффективны, и подставные группы, общества дружбы и агенты влияния все еще имеют место в наши дни.

Тогда как такие финансируемые государством СMИ как RT, Ruptly и Sputnik, определенно, являются частью «информационного блицкрига», анализ их содержания и тем может дать жизненно важные свидетельства о наличии в «реальном мире» осуществляемых в настоящее время активных мероприятий. Как было установлено 25 лет тому назад, также как и сейчас, российские финансируемые государством СМИ являются элементом «белой пропаганды» в симбиотической, самоподдерживающей себя системе дезинформации. В России Путина государственный механизм подрывной деятельности является повторением своего советского предшественника, почти полностью соответствуя следующему описанию, данному в докладе ЮСИА от 1992 года:

«Черные» (КГБ), «серые» (Христианская мирная конференция) [советская подставная группа] и «белые» (Агентство печати «Новости») элементы аппарата советских активных мероприятий работали вместе, создавая непрерывную сеть, которая генерировала и распространяла послания советских специалистов по активным мероприятиям, в то же время скрывая их роль в этой кампании с начала и до конца. ${ }^{64}$

62 Schoen and Lamb, "Deception, Disinformation, and Strategic Communications," 9. Soviet Active Measures in the "Post-Cold War" Era. Цитата из раздела, озаглавленным "New Thinking in Perspective: The Soviet View."

64 Там же. Цитата из раздела, озаглавленного “Manipulation of the Russian Orthodox Church." 


\section{Разбор конкретного примера №1: Манипулирование СМИ, фабрики троллей и полезные идиоты}

Персонал КГБ, используя новые пишущие машинки и работая в перчатках, чтобы не оставлять отпечатков пальцев, печатал сотни обидных анонимных писем и рассылал их десяткам африканских миссий. Письма, как будто бы написанные супремасистами и обыкновенными американскими гражданами, были полны яростных расистских филиппик. Африканские дипломаты предавали гласности некоторые из этих писем в качестве примеров расизма, все еще беснующегося в Америке, и сотрудники американской и иностранной прессы часто их цитировали.

- Олег Калугин, $1994^{66}$

Во время Холодной войны одной из самых широко используемых технологий советских активных мероприятий было манипулирование мировыми СМИ через сфабрикованные истории. Ориентируясь в основном на аудиторию третьего мира, КГБ следовал методологии, которую можно подытожить как внедрение, выдерживание и распространение.

Как описано в Исследованиях в сфере разведки, фальшивые сюжеты сначала разрабатывались сотрудниками КГБ как часть более широкой дезинформационной кампании, и затем внедрялись в легко манипулируемую среду СМИ - обычно в третьем мире. 67 Затем сюжет подхватывался местными новостными медиа, и ему давалось время на выдерживание. ${ }^{68}$ Через некоторое время, в зависимости от «липучести» сюжета, после того как он набирал достаточную

65 Schoen and Lamb, "Deception, Disinformation, and Strategic Communications," 6.

${ }^{66}$ Oleg Kalugin, Spymaster: My Thirty-Two Years in Intelligence and Espionage Against the West (New York, NY: Basic Books, 2009), впервые опубликована как The First Directorate (n.p.: St. Martin's Press, 1994), 54.

67 Boghardt, "Operation INFEKTION: Soviet Bloc," 3.

68 Там же, 3.
В 1983 Patriot, просоветская индийская газета, которая часто публиковала материалы, поставляемые агентами КГБ, выпустила материал, в котором утверждалось, что вирус ВИЧ создан американскими военными и используется ими как оружие. Пару лет эта история появлялась во второстепенных СМИ, которые находились под контролем КГБ или симпатизировали СССР. После этого инкубационного периода в 1985 году клевета была подхвачена официальной советской еженедельной газетой, публикующей новости культуры, Литературной газетой. После этого история быстро начала распространяться. Только в 1987 году она появилась более 40 раз в контролируемой Советами прессе и была перепечатана или повторена в эфире более чем в 80 странах на 30 языках. В то время вирус ВИЧ вызывал ужас и мало кто понимал, как он действует, поэтому эта советская дезинформация была особенно вредной для образа США.

- Флетчер Шон \& Кристофрер Лэмб 65 
популярность на более мелких рынках, более крупные органы советской печати подхватывали его и начинали распространять среди более широкой аудитории. ${ }^{69}$

Хотя такое манипулирование СМИ для западной аудитории было легко распознать и игнорировать, иногда даже большие западные СМИ попадались на удочку и распространяли такие истории. Даже если западные СМИ не подхватывали сюжет, все равно семена сомнения бывали посеяны, и часто слухи и конспиративные теории находили обратно путь на Запад и в общественное сознание. По существу, применяя во время Холодной войны манипулирование СМИ, КГБ «заражало» своей дезинформацией задолго до эпохи Интернета.

Как сейчас часто говорят, «В Интернете никто не знает, что вы собака», и сегодня для русской дезинформации гораздо легче заражать публику без легиона пишущих машинок и кучи почтовых марок. ${ }^{70}$ Схема внедрять, вынашивать и распространять была замещена схемой твитнуть, ретвитнуть, повторять.

К примеру, в статье, озаглавленной «Агентство», Нью-Йорк таймс проливает свет на зачаровывающий восход российских так называемых «фабрик троллей». Организация, чей профиль представлен в статье, находится В Санкт-Петербурге и известна как Агентство интернет-исследований. ${ }^{71}$ Согласно статье, «про это агентство известно, что оно нанимает сотни русских для того, чтобы они посылали посты с прокремлевской пропагандой онлайн, используя фальшивую самоличность, в том числе в Твиттере, с тем, чтобы создать иллюзию существования большой армии приверженцев». ${ }^{72}$ Далее рассказано про интервью Людмилы Савчук, бывшего сотрудника агентства, ставшей активистом борьбы с такой практикой, которая объясняет распорядок работы: «Два двенадцати часовых рабочих дня подряд, потом два дня отдыха. Кроме отработки двух смен, она должна была выполнить норму из пяти политических постов, 10 неполитических и от 150 до 200 комментариев постов других сотрудников». ${ }^{73}$

Согласно бывшему собственнику фабрики троллей Платону Маматову, который также представлен в статье, «существуют десятки предприятий, подобных его фабрике, работающих на государственную власть на всех

69 Там же, 3.

70 “On The Internet, Nobody Knows You're a Dog," Wikipedia, https://en.wikipedia.org/ wiki/On_the_Internet,_nobody_knows_you\%27re_a_dog (по состоянию на 19 августа 2015).

71 Adrian Chen, "The Agency," The New York Times, 2 June 2015, www.nytimes.com/ 2015/06/07/magazine/the-agency.html (по состоянию на 20 июня 2015).

72 Там же.

73 Там же. 
уровнях». ${ }^{74}$ В «Агентстве» в Санкт-Петербурге Савчук была одной из предположительно 400 сотрудников. ${ }^{75}$

Настоящий масштаб этих относительно новых тролль-операций неизвестен и недостаточно изучен, что критически опасно. Однако, похоже, что фермы троллей выполняют определенное число задач, связанных с подрывной деятельностью, и являются прямыми наследниками нескольких классических методов активных мероприятий.

Во-первых, их работа по загрязнению глобального информационного пространства «сделало для нормального интернетпользователя невозможным отделить правду от вымысла», таким образом формируя благоприятную среду для других российских кампаний по оказанию влияния и распространению посланий. ${ }^{77}$ Кроме того, «волны троллей и ботов регулярно продвигают пропутинские хэштэги» и сюжеты, распространяя послания Кремля с таким размахом, который был невозможен до эпохи Интернета и социальных медиа. $^{78}$

Хотя примеры превращения социальных медиа в «оружие» становятся все более обычными,

Агенты влияния - это иностранцы, которые были рекрутированы КГБ с тем, чтобы использовать их для оказания влияния на мнения иностранной общественности и иностранных правительств. Агенты влияния очень полезны, поскольку они воспринимаются как лояльные патриоты своих стран, которые просто выражают свое собственное личное мнение, а не читают тексты, написанные в КГБ ... Кампании по оказанию скрытного влияния, которые они ведут публично или частным образом, являются наиболее трудным для идентификации типом активных мероприятий, так же и потенциально наиболее эффективным, если агент влияния является высшим представителем власти или уважаемой публичной фигурой.

- Доклад ЮСИА, Советские активные мероприятия в эпохе после Холодной войны, 1988-1991

один инцидент от 2014 года показывает, как эффективность мероприятий по распространению кремлевских хэштегов может быть увеличена с помощью американской звезды - полезного агента влияния, который, может быть вслепую, способствует кремлевской пропаганде. Пример - Александр Овечкин, очень известный и очень популярный хоккеист, играющий в американской Национальной Хоккейной Лиге (НХЛ). Рожденный в Москве, он несколько лет играл за московское «Динамо» и был членом национальной

\footnotetext{
74 Там же.

75 Там же.

76 Soviet Active Measures in the "Post-Cold War" Era. Цитата из раздела, озаглавленным "Agents of Influence."

77 Там же.

78 Там же.
} 
команды России на разных чемпионатах, на мировых первенствах и Олимпийских играх. ${ }^{79}$

В 2004 году он был кандидатом номер один в НХЛ, заключил контракт с Вашингтон Капиталс и начал играть в лиге в сезоне 2005-2006. Через два года он подписал самый высокооплачиваемый контракт в истории стоимостью в 124 миллиона долларов на 13 лет. ${ }^{80}$ За достижения на ледовом поле он был назван дебютантом года в 2006 году и наиболее ценным игроком в 2008, 2009 и снова в 2013 году. В настоящее время у него 365000 последователей в Инстаграме и более 1, 42 миллионов в Твиттере. ${ }^{81}$

28 августа 2014 года он опубликовал в Инстаграме свое профессиональное фото в тенниске, на которой была надпись «Нет войне». На фотографии он держит лист с надписью, неявно поддерживающей участие России в украинском конфликте, "\#SAVECHILDRENFROMFASCISM."

(Спасите детей от фашизма). Пост получил более чем 17,4 тысячи «лайк-ов», сразу достиг до его почти двух миллионов последователей в социальной сети и получил еще большую аудиторию, когда

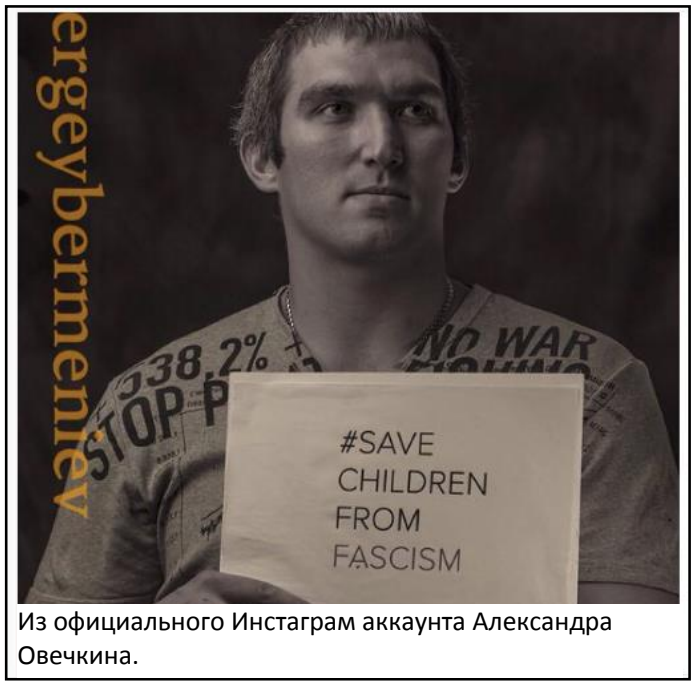
сюжет был подхвачен местными и мировыми СМИ. Через две недели (источник РИА «Новости») сюжет появился на английском языке на российском новостном интернет-агентстве «Спутник», которое рекламирует себя как «поставщик альтернативного новостного содержания» и открыто финансируется российским правительством. ${ }^{82}$ В сюжете Спутника подчеркивалась «сильная [западная] критика», которой подвергся Овечкин за свою фотографию. Несмотря на критику своей активности в социальной сети, Овечкин продолжил публиковать онлайн про-путинское содержание,

79 “Alexander Ovechkin," Wikipedia, http://en.wikipedia.org/wiki/Alexander_Ovechkin (по состоянию на 19 августа 2015).

80 Там же.

81 https://instagram.com/aleksandrovechkinofficial (по состоянию на 19 августа 2015); https://twitter.com/ovi8 (accessed 19 August 2015).

82 "Ovechkin Speaks Against Fascism in Ukraine, Faces Criticism From Americans," Sputnik News, 10 September 2014, http://sputniknews.com/world/20140910/ 192814040/Ovechkin-Speaks-Against-Fascism-in-Ukraine-Faces-Criticism-From.html (по состоянию на 19 августа 2015). 
широко пропагандируя кремлевские послания, и все еще является полезным инструментом в арсенале российских активных мероприятий.

\section{Разбор практического примера №2: вбивание клиньев между запад- ными союзниками с помощью агентов влияния и подставных групп}

Любимой стратегией для кампаний советских активных мероприятий было использование размолвок между западными союзниками - в частности, между членами ЕС и НАТО. Россия продолжает использовать эту стратегию и в наши дни. Европейский совет по внешним отношениям в 2007 году опубликовал доклад, который сфокусирован на некоторых из этих трещин, и в нем подчеркивается, что «неспособность ЕС достичь согласия по общей политике в отношении России» и демонстрация этого «позволили Кремлю увеличить свое влияние на ЕС через подписание двухсторонних энергетических контрактов, разыгрывание косовской карты, утверждение своего влияния на общих соседей и откладывание в долгий ящик работу по предотвращению распространения ядерного оружия». ${ }^{83}$

В докладе страны-члены ЕС классифицированы по их позиции в отношении России, причем Греция и Кипр выделены как «троянские кони, чьи правительства часто защищают позиции, близкие к российским интересам, и которые заявляли, что могут наложить вето на общие позиции ЕС. Доклад так же раскрывает такие малоизвестные факты, как то, что Кипр является самым большим официальным «инвеститором» в России благодаря большим российским капиталам, которые хранятся в его банках. ${ }^{84}$

Демонстрируя возможность появления российского «агента» в EC, или по крайней мере, возможность манипулирования высокопоставленными личностями, в апреле 2015 года Путин встретился с греческим премьерминистром Алексисом Ципрасом, еще больше усиливая фурор в связи с потенциальным выходом Греции из ЕС - так называемого «Грекзит»-а. Произошедшая в критический для кризиса момент, встреча Путина с премьер-министром была очень противоречива, как и комментарии Ципраса, касающиеся западных санкций против России. Ципрас сказал, что «мы неоднократно заявляли о нашем несогласии ... такова наша точка зрения, которую мы постоянно выражаем перед нашими коллегами в ЕС. Мы не думаем, что это является плодотворным решением. Это на практике объявление экономической войны». 85

Манипулирование политических групп является классической технологией активных мероприятий, и в настоящее время Россия оказывает влия-

83 Mark Leonard and Nicu Popescu, A Power Audit of EU-Russia Relations (London: European Council on Foreign Relations, 2007).

84 Там же.

85 David M. Herszenhorn and Liz Alderman, "Putin Meets With Alexis Tsipras of Greece, Raising Eyebrows in Europe," The New York Times, 8 April 2015, www.nytimes.com/ 2015/04/09/world/europe/putin-russia-alexis-tsipras-greece-financial-crisis.html (по состоянию на 12 августа 2015). 
ние на несколько таких групп в ЕС - их сценически громкие укусы входят в заголовки и расширяют влияние Кремля. Статья радио «Свободная Европа»/радио “Свобода» от июля 2015 года выявляет несколько инцидентов с участием французских групп, вероятно, связанных с российской кампанией активных мероприятий. К примеру, в ноябре 2015 года «правая партия «Национальный фронт» попала в заголовки ..., когда приняла ссуду в размере 11 миллионов долларов от российских кредиторов после переговоров между ее руководителем Марин ле Пен и представителями Москвы». ${ }^{86}$ Партия «Национальный» фронт придерживается анти-ЕС и анти-иммиграционной платформы, и ее называют «пророссийским блоком в парламенте EC». ${ }^{87}$ В мае 2014 года партия «Национальный фронт» стала одной из самых значительных партий Франции на европейской сцене ..., получив исторические 25 \% голосов на европейских выборах». ${ }^{88}$

Недавно сильно противоречивым примером российской манипуляции стала группа из десяти французских законодателей правого толка, посетившая Крым в июле 2015 года, «первая ... европейская делегация с момента непризнанной аннексии полуострова Россией». ${ }^{89}$ Находясь в Крыму, парламентарии сделали ряд спорных заявлений в поддержку крымского референдума о независимости (замечание: который ЕС считается незаконным) и заявили, что нет «никаких причин, чтобы Европа сохраняла санкции против России». ${ }^{90}$ Поездка, которая согласно статье французского министерства иностранных дел была «осуждена ... как нарушение международного права», была организована Ассоциацией «Франко-российский диалог», без сомнения, являющейся российской подставной группой и частью кампании «серых» активных мероприятий, направленной против Франции. ${ }^{91}$ Очевидным признаком этого является то, что сопредседатель группы, Владимир Якунин, является близким другом Путина с предположительно прошлым в КГБ. В марте 2014 года он был специально упомянут в списке Казначейства США из шестнадцати российских граждан, на которые были наложены индивидуальные санкции. Министерство финансов представило следующее обоснование:

${ }^{86}$ Claire Bigg, "Crimea Visit Spotlights Kremlin Sympathies Beyond French Fringes," Radio Free Europe / Radio Liberty, 29 July 2015, www.rferl.org/content/crimea-visitspotlights-kremlin-sympathies-beyond-french-fringes/27159124.html (по состоянию на 29 июля 2015).

87 Luke Harding, "We Should Beware Russia's Links With Europe's Right," The Guardian, 8 December 2014, www.theguardian.com/commentisfree/2014/dec/08/russiaeurope-right-putin-front-national-eu (по состоянию на 12 августа 2015).

88 Kim Willsher, "Marine Le Pen's confidence vindicated by Front National election triumph," The Guardian, last modified 25 May 2014, www.theguardian.com/world/ 2014/may/25/marine-le-pen-confidence-proves-vindicated-front-national (по состоянию на 19 августа 2015).

89 Bigg, "Crimea Visit Spotlights Kremlin."

90 Там же.

91 Там же. 
Владимир Якунин был назначен председателем совета директоров государственной компании Российские Железные Дороги в июне 2005 года; с тех пор он остается главой компании. Якунин был назначен благодаря своему официальному положению в российском правительстве, но и также изза того, что является доверенным лицом Путина. Якунин регулярно советуется с Путиным по проблемам компании Российские Железные Дороги. Кроме того, Якунин сопровождает Путина во многих внутренних и международных поездках. Якунин встретился с Путиным, когда они оба работали в Санкт-Петербурге. Якунин решил создать бизнес-центр в городе и договорился с Путиным о поддержке. Кроме того, Якунин стал членом совета директоров Балтийской Морской Пароходной компании по указанию Путина. Якунин и Путин были соседями по даче на берегу озера Комсомольск, и они стали со-основателями дачного кооператива «Озеро» в ноябре 1996 года. ${ }^{92}$

Якунин только один из многих силовиков Путина, и Ассоциация французско-русского диалога является только одной из бесчисленных обществ дружбы и дискуссионных клубов. Со странно звучащими именами, как например Дискуссионный клуб «Валдай» и многие другие, они остаются эффективным средством для манипулирования общественным мнением и рупором кремлевских посланий. ${ }^{93}$

\section{Разбор практического примера №3: защита дойной коровы с помо- щью подставных групп, шпионажа и СМИ}

Россия - это государство-рантье, ее энергетический сектор обеспечивает «20-25 \% ВНП, 65 \% всего экспорта и 30 \% государственного бюджета». ${ }^{94}$ В 2015 году низкие цены на нефть опустошили одномерную российскую экономику. ${ }^{95}$ При отсутствии экономического разнообразия любой срыв энергетических доходов является серьезной угрозой, - и новая американская фрекинговая индустрия является большой угрозой. Как подробно описано в недавней статье в National Review, Россия начала применять «тройственную стратегию» для ослабления быстро развивающейся фре-

92 "Treasury Sanctions Russian Officials, Members of the Russian Leadership's Inner Circle, and an Entity for Involvement in the Situation in Ukraine," Press Center: US Department Of The Treasury, March 20, 2014, по состоянию на 12 августа 2015, http://www.treasury.gov/press-center/press-releases/Pages/jl23331.aspx.

93 В противоречивой обстановке, в августе 2015 года Якунин ушел с поста главы российских железных дорог и стал сенатором, представляющим Калининградский регион. В октябре 2015 года он заявил о планах основать мозговой центр по вопросам глобальной политики.

94 "Key Macroeconomic Indicators," Ministry of Economic Development of the Russian Federation, http://www.ved.gov.ru/eng/general/economy/ (по состоянию на 12 августа 2015).

95 Anna Andrianova, "Russian GDP Plunges 4.6\%," Bloomberg Business, 10 August 2015, http://www.bloomberg.com/news/articles/2015-08-10/russian-economy-shrinks-46-as-oil-slump-risks-deeper-recession (по состоянию на 12 августа 2015). 
кинговой промышленности США. ${ }^{96}$ Согласно этой статье, Россия использует сочетание классических активных мероприятий, в том числе: «тайное финансирование экологических групп на Западе» и шпионаж, направленный против «американской энергетической индустрии». ${ }^{97}$ Далее в докладе описан рассматриваемый в настоящее время в Министерстве правосудия США случай, в котором трое агентов российской Службы внешней разведки (СВР) обвиняются в «шпионаже против проводимых в Соединенных Штатах работ по развитию альтернативных энергетических ресурсов». ${ }^{98}$

В поддержку этих активных мероприятий, кампания постоянно подкрепляется финансируемой государством пропагандой, во главе которой $\mathrm{RT}$, которое «недавно выпустило часовой документальный фильм, который 'документирует' болезни, предположительно вызываемые применением фрекинга в американской глубинке». 99 Такие активные мероприятия против фрекинга, вероятно, будут продолжаться, причем ожидается, что к этой кампании присоединиться Русская православная церковь, которая будет озвучивать озабоченность экологическими последствиями гидравлического фрекинга.

\section{Заключение}

Не говорите "Нам нужна новая перезагрузка с Россией». И это говорю я, человек, который сказал эти слова президенту, когда в последний раз был в Овальном кабинете. - Майкл Макфол, бывший посол США в России, 2015 100

К концу Холодной войны ДРНБ 75 и Доктрина Рейгана обеспечили ясное, всеохватное стратегическое руководство для американского государственного управления в целом - «единую партитуру», которая синхронизировала подход США к Советскому Союзу. Сегодня не существует такого руководящего документа для американской политики в отношении Российской Федерации. Хотя располагающая ядерным оружием Россия не является такой же экзистенциальной угрозой для Соединенных Штатов, какой был Советский Союз, нынешнее отсутствие стратегии США в отношении России порождает замешательство в государственных ведомствах и мешает целенаправленности работы по формированию американской реакции на российскую агрессию. ${ }^{101}$ В ситуации, когда политика США интер-

96 Tom Rogan, "Russia's War on Fracking," National Review, 3 February 2015, http://www.nationalreview.com/article/397755/russias-war-fracking-tom-rogan (по состоянию на 24 июня 2015).

97

Там же.

98 Там же.

99 Там же.

100 Olivier Knox, "Russia 'Reset' Architect to Next President: Don't Try That Again," Yahoo Politics, 28 May 2015, https://www.yahoo.com/politics/russia-reset-architectto-next-president-dont-120051660936.html (по состоянию на 9 июля 2015).

${ }^{101}$ Crawford, "Joint Chiefs Nominee." 
претируется индивидуальными акторами на их усмотрение, без единой ясно определенной конечной цели, вероятным исходом является некоординированный неэффективный ответ и напрасные расходы. Кроме того, отсутствие единого фронта, наличие несогласованностей между государственными органами и ведомствами дают возможность эксплуатировать их в неблагоприятном направлении. Как описано в одном обзоре отношений соперничества между ЕС и Россией, формирование общей стратегии в отношении России для 28 стран-членов ЕС является еще большим вызовом, и его разрешение почти невозможно. ${ }^{102}$

Россия является самым большим государством в мире и граничит с пятью членами ЕС. Численность ее вооруженных сил составляет приблизительно 800000 военнослужащих, предположительно 20000 танков и более 1300 летательных аппаратов. ${ }^{103}$ Она располагает предположительно 7500 ядерными боеголовками и проводит учения с ракетами «Искандер» с тактическими ядерными боеголовками в Калининграде. ${ }^{104}$ При положении, что Путин может остаться у власти еще девять лет и эксперимент с «перезагрузкой» можно считать неуспешным, США и другие страны должны разработать комплексную стратегию, как вести себя с Россией. ${ }^{105}$ Без ясных «конечных состояний» невозможно создать эффективные «пути» и «средства».

Несмотря на отсутствие определенной стратегии США, ряд мозговых центров и военных руководителей обсуждают новые подходы для будущего, в котором все больше будет применяться «гибридная война». Одна из этих концепций, так называемая стратегия «третьего переноса», предполагает будущее, в котором «преимущество США в боевых способностях ... в операциях без участия людей, в воздушных операциях увеличенного радиуса и пониженной наблюдаемости, в подводной войне и в комплексном системном инжиниринге, интеграции и операциях ... может быть использовано для формирования глобальной сети для наблюдения и нанесения ударов (ГСНУ)». ${ }^{106}$ Стратегия предполагает создание сети взаимосвязанных автономных стелт беспилотных летательных аппаратов, беспилотных подводных аппаратов, подводных складов «полезной нагрузки», вы-

102 Leonard and Popescu, A Power Audit of EU-Russia.

103 Jonathan Masters, "The Russian Military," Council on Foreign Relations, 20 March 2015, http://www.cfr.org/russian-federation/russian-military/p33758.

104 "Status of World Nuclear Forces," Federation of American Scientists (FAS), http://fas.org/issues/nuclear-weapons/status-world-nuclear-forces/ (по состоянию на 17 августа 2015); Vladimir Isachenkov, "Russia Is Putting State-of-the-Art Missiles in Its Westernmost Baltic Exclave," Business Insider, 18 March 2015, www.businessinsider.com/russia-placing-state-of-the-art-missiles-in-kaliningrad2015-3?ор=1 (по состоянию на 17 августа 2015).

${ }^{105}$ Knox, "Russia 'Reset' Architect."

${ }^{106}$ Robert Martinage, Toward a New Offset Strategy: Exploiting U.S. Long-Term Advantages to Restore U.S. Global Power Projection Capability (Center for Strategic and Budgetary Assessments, 2014), ii, v. 
сокоэнергетических лазеров и противокосмических способностей. ${ }^{107}$ Эта стратегия направлена на компенсирование способностей, приобретенных после Холодной войны потенциальными противниками, и она позволит США сохранить военное превосходство еще на долгое время в будущем. Приверженцы этого третьего переноса признают, однако, что он не является панацеей. Эта исключительно дорогостоящая инициатива не учитывает ряд фундаментальных изменений, произошедших в нашем все более глобализованном мире.

Многие эксперты считают, что характер войны претерпел драматические изменения, и будущие конфликты будут драматически отличаться от конфликтов в прошлом. Как разъясняет Томас Ниссен из датского Королевского колледжа обороны, «Война уже не означает, что воюет одно государство против другого (в конвенциональном смысле), но речь идет об идентичности и представлениях об идентичности и космополитизме (включения) против партикуляризма (исключения/национализма). Поэтому современные войны касаются в большей степени контроля над населением и процессом принятия политических решений, чем контроля над территорией». ${ }^{108}$

Последние китайская и российская военные доктрины учитывают эту теорию, давая ясно понять, что в будущем глобальное информационное пространство станет полем сражений, - причем конфликты будут выигрываться и проигрываться еще на нулевой фазе развития конфликта. Китайская стратегия "трех войн» основывается на «правовой войне, войне в сфере СМИ и психологической войне», а так называемая российская "Доктрина Герасимова» отдает предпочтение «широкому использованию политических, экономических, гуманитарных и других невоенных мероприятий». ${ }^{109}$ Имея это в виду, очень вероятно, что использование подрывной деятельности и кампаний активных мероприятий в будущем только будет расширяться. Очень важно, чтобы США и их союзники распознали эту угрозу и быстро разработали решения для противодействия ей.

\section{Рекомендации}

В своем докладе Угроза нереальности Петр Померанцев и Майкл Вайс признают усиливающуюся тенденцию превращения информации в оружие, предлагают ряд глубоких стратегий для противодействия эффективности скоординированной дезинформации и пропагандистских кампаний.

\footnotetext{
107 Там же.

108 Thomas E. Nissen, The Weaponization of Social Media (Copenhagen, Denmark: Royal Danish Defense College, 2015) 8.

${ }^{109}$ Timothy A. Walton, China's Three Warfares (Herndon, VA: Delex Systems, 2012); Sam Jones, "Ukraine: Russia's New Art of War," Financial Times, 28 August 2014, www.ft.com/cms/s/2/ea5e82fa-2e0c-11e4-b760-00144feabdc0.html (по состоянию на 17 августа 2015).
} 
Также, в проекте доклада НАТО о противодействии пропаганде, репортер Витольд Ващиковский предлагает ряд рекомендаций Альянсу. ${ }^{1}$

В то время как Померанцев и Вайс признают вклад РГАМ, они также понимают ограничения подходов и методологии времен Холодной войны в современном связанном мире. ${ }^{111}$ Несмотря на это, однако, опыт этой группы все еще может дать ряд критически важных уроков и хороших практик для будущих государственных усилий по борьбе с активными мероприятиями и дезинформации. Также как старые советские технологии были модернизированы путем использования современных «средств», уроки РГАМ могут быть адаптированы с использованием современных технологий для обеспечения большего взаимодействия, коммуникации и быстрой реакции, чем когда-либо раньше.

Некоторые из этих уроков в сочетании с рекомендациями воспроизведены ниже. Любые будущие меры для выявления активных мероприятий потенциальных противников должны начинаться тщательным прочтением этих замечательных публикаций, поскольку первым шагом в разоблачении кампании активных мероприятий является осведомленность о существовании этой проблемы. Сегодня такая осведомленность прискорбно отсутствует.

\section{Адаптировано из Померанцев \& Вайс, Угроза нереальности}

Рекомендации для противодействия превращения информации в оружие:

- Создать «Трансперенси Интернешнл» для дезинформации

- Создать «Хартию по дезинформации» для СМИ и блоггеров

- Учредить должность/нанять «редакторов по контра-дезинформации» для СМИ

- Улучшить кампании по повышению осведомленности общественности в направлении использования/распространения пропаганды и усовершенствовать раскрытие личных интересов мозговыми центрами, пандиты, и т.д.

- Целенаправленная онлайн работа в помощь тем, кто оказался под влиянием интенсивной пропаганды: эквивалентная онлайн социальная работа для тех, кто входит в тяжело пострадавшие сферы.

Рекомендации по противодействию превращения денег в оружие:

- Создать организации и некоммерческие финансовые потоки для поддержки журналистских расследований коррупции (Стратегические исследования в сфере коррупции). Создать Журналистский фонд для дел о публичном оскорблении, предназначенный для защиты журналистов от реваншистских судебных преследований

\footnotetext{
${ }^{110}$ Witold Waszczykowski, The Battle for the Hearts and Minds: Countering Propaganda Attacks Against the Euro-Atlantic Community (NATO Parliamentary Assembly, Committee on the Civil Dimension of Security, 2015).

${ }^{111}$ Pomerantsev and Weiss, The Menace of Unreality, 41.
} 
- Поддержка работы по расследованию коррупции и/или пропаганды с участием широкой аудитории, с НПО в качестве вектора.

Рекомендации по противодействию превращения идей в оружие:

- Восстановить прозрачность и лояльность между мозговыми центрами и другими: поощрять добровольное обнародование потоков финансирования

- Создать «Альтернативный Валдай» для борьбы с проблемами, порожденными Валдаем, прокремлевскими НПО и использованием Православной церкви. Он мог бы собрать вместе представителей мозговых центров, экспертов и политиков с тем, чтобы возобновить дискуссию о последствиях российской политики по региональным и глобальным проблемам.

\section{Адаптировано из проекта доклада НАТО, подготовленного Ви- тольдом Ващиковским "Доклада о противодействии пропаган- дистским атакам против евро-атлантического сообщества»}

- Противодействие российской информационной войне следует поднять в начало повестки дня евро-атлантического сообщества

- В рамках парламентской ассамблеи НАТО необходимо создать специфические подкомиссии или другие органы ассамблеи, которые будут осуществлять постоянный мониторинг эволюции этой угрозы и докладывать Ассамблее по этой проблеме на регулярной основе

- Разработать более координированный нарратив и набор аргументов, опровергающих мифы, культивированные Москвой, следуя примеру инициативы НАТО «расставить точки над ' $и$ '»

- Дальнейшее усиление управления НАТО по публичной дипломатии (УПД) и соответствующих органов ЕС для улучшения способности ЕС быстро реагировать на наиболее очевидные случаи дезинформации

- Политику в отношении классифицированной разведывательной информации следует пересмотреть с тем, чтобы позволить сотрудникам управления публичной информации использовать менее чувствительную информацию, в том числе спутниковые изображения с тем, чтобы опровергать дезинформацию

- Создать платформы для обмена наилучшими национальными практиками в рамках евро-атлантического сообщества и обозначивания потенциальных информационных угроз безопасности

- Изменить законодательство для усиления таких правовых контрмер, как наложение штрафов за использование речи, прокламирующей ненависть и за очевидную дезинформацию

- Поощрять ведущие мировые СМИ разрабатывать системы высоких журналистских стандартов и поощрять независимые глобальные активистские организации осуществлять мониторинг соблюдения этих стандартов 
- Оказывать поддержку международным и национальным инициативам СМИ на русском языке, в том числе запуску финансируемого сообща телевизионного канала на русском языке

- Изменение законодательства в направлении усиления прозрачности финансирования СМИ, НПО и мозговых центров

- Делать четкое различие между российскими журналистами, как бы ни были они пристрастными, и пропагандистами, постоянно искривляющими и фабрикующими информацию

- Применять индивидуальные санкции, ограничивающие поездки, против наиболее активных пропагандистов и политтехнологов

- Рассмотреть такие инновационные и недорогостоящие меры, как более широкое использование сатиры: запуск ТВ шоу или раздела в газете, которые описывают и высмеивают наиболее неуклюжие случаи фальсификации информации

- Инвестировать в исследования и в образование подходящих людей на предмет распознавания, обнародования и реакции на интернет троллей и на оркестрованные атаки «троллей»

- Увеличить помощь в создании способностей таким странам, как Украина, в сфере стратегических коммуникаций

- Организовать обзоры для регулярного мониторинга влияния российской пропаганды на население стран евро-атлантического пространства

- Поощрять и способствовать выражению мнений представителей русской диаспоры с демократическими взглядами

- Помогать сообществу профессиональных историков давать достоверный ответ на псевдонаучные теории, которые прославляют сталинизм, унижают государственность соседей России и фальсифицируют исторические факты

- Поощрять такие низовые инициативы, как StopFake.org.

Уроки работы Рабочей Группы по Активным Мероприятиям, адаптированные согласно Шон и Лэмб, «Заблуждение, дезинформация и стратегическая коммуникация; как одна межведомственная группа изменила многое»

РГАМ действовала, придерживаясь методологии - изготовление доклада, проведение анализа и опубликование результатов:

- Доклад: Получены и сведены воедино доклады представительств ЮСИА по всему миру, ЦРУ и расследования ФБР (замечание: сегодня функции ЮСИА могут выполняться при усиленной поддержке группами по публичным делам посольств США)

- Анализ: Анализ проводился в Вашингтоне; члены группы были из разных ведомств и встречались раз в неделю. Состав варьировал, и члены менялись в зависимости от их ежедневной занятости 
- Опубликование: Группа изготавливала доклады о советской дезинформации на полурегулярной основе. Доклады были несекретными и циркулировали между ведомствами и прессой. Группа также разработала «передвижное представление», чтобы способствовать обучению персонала посольств, а также национальные разведывательные службы и национальные СМИ

- Публикуя свои доклады и проводя свои передвижные семинары, группа повышала осведомленность, что запускало новый цикл докладов. Чем больше они публиковали информации о советских дезинформационных мероприятиях, тем чаще и тем более качественные доклады они получали с мест.

РГАМ оставалась сфокусированной на основной задаче, не допуская «расползания миссии» путем дефинирования ограниченного набора целей:

- Она ограничила свою миссию до противодействия советским операциям по оказанию влияния, которые можно было разоблачить убедительно с использованием несекретной или рассекреченной информации

- Эта методология позволила им сосредоточиться на случаях, которые, вероятнее всего, были «выигрышными»

- Она оставалась сосредоточенной на разоблачении дезинформации (прямой лжи), а не на пропаганде (убеждении).

Подход РРГАМ к противодействию активным мероприятиям включал следующие критически важные элементы:

- Эффективную контрразведку

- Постоянное и продолжающееся разоблачение дезинформации

- Соблюдение высочайших стандартов точности

- Поддержание безупречного послужного списка по точности и достоверности, что позволило группе сохранять доверие к себе (их продукты соответствовали очень высоким внутренним стандартам, как будто материалы готовились для судебных заседаний с присяжными заседателями, что обеспечивало качество и неоспоримость их докладов по советской дезинформации)

- Советская ложь разоблачалась не с идеологических, а с профессиональных позиций.

Ведущим ведомством для РГАМ был Государственный департамент:

- Это создавало дипломатическое доверие к группе

- Способствовало тому, что работа группы администрировалась с политической чуткостью.

Для продолжения существования и обеспечения успеха группы была необходима поддержка и защита со стороны высшего руководства: 
- У группы покровители были на всех уровнях исполнительной власти

- Руководители Конгресса вырабатывали требования, выдвигали членов группы и лоббировали в пользу создания институциональных способностей создавать доклады

- Группе было нужно сильное руководство для обеспечения эффективности своей работы:

○ Эффективным оказалось, чтобы руководство группой осуществлял Заместитель помощника государственного секретаря

○ Политические назначения на высоких должностях обеспечивали покровительство на высоком уровне.

РГАМ была недорогостоящим решением для борьбы с советской дезинформации. Цена разоблачения советской дезинформации была незначительно по сравнению с тем, что Советы тратили на ее создание и распространение:

- Производство высококачественных результатов с минимальными ресурсами делало плодотворное сотрудничество с руководящими организациями более вероятным

- Группе не были нужны какие-то специфические для ее миссии ресурсы:

- Она использовала только часть рабочего времени существующих экспертов и аналитиков по разведке Госдепартамента

○ У членов группы не было бюджета, который включал бы что-либо, кроме нормальных дорожных и представительских расходов, которые контролировались их начальством по основному месту работы.

Рассекречивание межведомственных докладов и других свидетельств было очень важным для успеха группы, предоставляя солидные «доказательства», необходимые для поддержки их «случаев»:

- Рассекречивание, однако, не было бесспорным: обмен информацией осуществлялся не всегда из-за интересов руководящих ведомств, связанных с нераскрытием источников и методов.

Среди членов группы опыт и преданность работе ценились выше рангов и должностей.

\section{6 авторе}

Стив Абрамс - офицер Сухопутных войск США для работы в иностранных регионах. Он говорит на русском и специализировался по Евразийскому региону. В настоящее время он учится в Школе имени Джонса Хопкинса в Вашингтоне, округ Колумбия, для получения степени магистра по менеджменту конфликтов. E-mail: abrams.steve@gmail.com. 